\title{
Economic analysis for oregano under irrigation considering economic risk factors
}

\author{
Patricia Angélica A Marques ${ }^{1}$; Lineu Bernardi Filho²; José Antônio Frizzone ${ }^{1}$ \\ 'USP-ESALQ, Depto. Eng. de Biossistemas, Inst. Nac. Ciência e Tecnologia, Eng. da Irrigação, C. Postal 09, 13418-900 Piracicaba-SP; \\ paamarques@usp.br; frizzone@usp.br; ${ }^{2}$ UNOESTE, 19067-175 Presidente Prudente-SP; lineufilho@hotmail.com
}

\begin{abstract}
The oregano is a plant, rich in essential oil and very used as spice in the preparation of foods. The objective of this paper was to analyze the viability of irrigation for oregano in Presidente Prudente, São Paulo state, Brazil, including economic risk factors, their effect on irrigation total cost, as well as the different pumping kinds. The Monte Carlo simulation was utilized to study the economic factors: fixed cost, labor, maintenance, pumping and water. The use of irrigation for the oregano in the region of Presidente Prudente is indicated because of its economic feasibility and the reduced risks. The average values of the benefit/cost for all water depths tested were higher than 1 , indicating viability. The use of irrigation promoted lower risks compared to the non irrigated crop. The micro irrigation system presented greater sensitivity to changes of prices of the equipment associated to the variation of the useful life of the system. The oregano selling price was the most important factor involved in annual net profit. The water cost was the factor of lesser influence on the total cost. Due to the characteristic of high drip irrigation frequency there was no difference between the tariffs based in use hour of electric energy classified as green and blue, which are characterized by applying different rates on the energy consumption and demand according to the hours of day and times of the year. For the studied region it was recommended drip irrigation water management of oregano with the daily application of $100 \%$ of pan evaporation Class A using electric motor with tariffs blue or green.
\end{abstract}

Keywords: Origanum vulgare, pumping, economic viability, risk analysis, medicinal plants.

\section{RESUMO}

Análise econômica do orégano irrigado considerando fatores de risco econômico

O orégano é planta rica em óleo essencial, muito usada como tempero na preparação de alimentos. $\mathrm{O}$ objetivo deste trabalho foi a análise da viabilidade econômica do uso da irrigação em orégano para a região de Presidente Prudente (SP), com a inclusão do risco econômico e a análise do efeito dos fatores econômicos sobre o custo total da irrigação, bem como as diferentes formas de bombeamento. Utilizou-se a simulação por Monte Carlo para os fatores econômicos estudados: custo fixo, mão de obra, manutenção, bombeamento e água. Baseado neste estudo concluiu-se que o uso da irrigação para o orégano na região de Presidente Prudente é indicado devido a sua viabilidade econômica e redução dos riscos. Os valores médios obtidos da relação benefício/custo para todas as lâminas de irrigação testadas foram superiores a 1 , indicando viabilidade. $O$ uso da irrigação promoveu riscos inferiores aos do cultivo de sequeiro. A irrigação localizada apresentou maior sensibilidade à variação dos custos de aquisição associado à variação da vida útil do sistema. O preço de venda do orégano foi o fator que mais influenciou na receita líquida anual. O custo da água foi o fator de menor influência no custo total. Devido à característica de alta frequência da irrigação localizada não se observou diferenças entre as tarifas horosazonais verde e azul. A tarifa horosazonal é caracterizada pela aplicação de valores de tarifas diferenciados de consumo de energia elétrica e de demanda de acordo com as horas de utilização do dia e dos períodos do ano. Para a região estudada o manejo adequado da irrigação do orégano por gotejamento é a aplicação diária de $100 \%$ da evaporação medida no tanque Classe A com motor elétrico utilizando tarifa verde ou azul.

Palavras-chave: Origanum vulgare, bombeamento, viabilidade econômica, análise de risco, plantas medicinais.

\section{(Recebido para publicação em 3 de dezembro de 2010; aceito em 5 de abril de 2012)} (Received on December 3, 2010; accepted on April 5, 2012)

$\mathrm{T}$ he oregano (Origanum vulgare), a small aromatic plant of Lamiaceae family, is originated from the Mediterranean region (Mastro et $a l ., 2004)$. Since it is rich in essential oil, its use is very common in food preparation. As medicinal plant, it is used for stomachache and diuretic. Several medicinal, aromatic and spice plants are produced through the use of supplemental irrigation, like oregano, chamomile, sage and peppermint. In his study, Hadid et al. (2004) obtained the yield of $7,000 \mathrm{~kg} \mathrm{ha}^{-1}$ using the supplemental irrigation and observed that the oregano, when irrigated, showed economic benefits higher than the ones obtained in big crops, giving 24 times more payback than the wheat cultivated in arid regions of Syria.

The irrigation is justified as an essential economic resource to increase the yield of the crops in regions where the insufficiency or poor distribution of rainfall affects the farm income. However, the economic viability is an indispensable factor for its adoption among farmers (Silva et al., 2003; Mousinho et al., 2008). According to Almeida et al. (2004) and Oweis \& Hachum (2009), the viability of a production system depends on the appropriate management, and it needs economic analysis. Silva et al. (2007) add that the promising prospect of the adoption of the irrigation should 
be studied and analyzed carefully, according to planning, design, management and development of the crop. They also believe that irrigation can help the farmers a great deal. However, the risks of the adoption of an irrigated agriculture should be carefully planned, always aiming a gross income higher than the expenses.

The high investment on irrigated agriculture in works and acquisition of equipment as well as energy costs and labor for the operation of the system, represent important extra expenses, which should be paid by the increase of the yield provided by water supply to the plants (Clark et al., 1993; Oweis \& Hachum, 2009).

The simulation method by Monte Carlo provides the calculus of different combinations that probabilistically can occur, obtaining as a result not a deterministic value of economic factors but a distribution of frequencies (Frizzone \& Silveira, 2000; Iglesias et al., 2003). The combined possibilities of net benefit are calculated, generating a normal distribution in which it is possible to infer about the probabilities of net benefit higher than zero to the analyzed situations.

This study aimed to analyze the economic viability of the use of irrigation in oregano crop for Presidente Prudente region, São Paulo state, Brazil, including the economic risk through the variation of economic factors: fixed cost, labor, maintenance, pumping and water, as well as the different costs of forms of pumping water.

\section{MATERIAL AND METHODS}

To analyze the economic viability of the irrigation, the yield obtained in a field research by Marques et al. (2009) was used. The experiment was carried out in Presidente Prudente city (São Paulo state, Brazil). The weather is according to Köppen, aw mesothermal, with hot summers and dry winters. In this research, completely randomized design was used, considering $0 ; 25$; 50; 75 and 100\% ECA (the Class A pan evaporation). The fresh oregano yields obtained were $3,127.20$; 4,985.10;
5,263.80; 5,699.30 and 8,089.70 kg $\mathrm{ha}^{-1}$ of fresh oregano respectively for irrigation depths of $0 ; 54.20 ; 108.41$; 162.62 and $216.82 \mathrm{~mm}$ respectively.

The local soil, classified as Arenic Ultic Orthoxic Tropudalf (EMBRAPA, 1999), shows water content at field capacity $(\Theta c c)=21.9 \%$; water content to wilting point $(\Theta \mathrm{pmp})=6.9 \%$; bulk density $=1.66 \mathrm{~g} \mathrm{~cm}^{-3}$ and total porosity of $37.13 \%$; for the depth of $0-0.20 \mathrm{~m}$ and Өcc $=20.6 \% ;$ Өpmp $=4.9 \% ; \mathrm{ds}=1.64$ $\mathrm{g} \mathrm{cm}^{-3}$ and total porosity of $39.97 \%$ for the depth of $0.20-0.40 \mathrm{~m}$.

The water storage capacity in soil was obtained through the adjusted soil water retention curve (Van Genuchten, 1980) and calculated according to the root system growth in each crop phase.

To calculate the cost of pumping using electric motor, electricity rates prevailing in the year of 2009 were used (green, blue and conventional tariffs) for Presidente Prudente, Caiuá Company (ANEEL, 2009). To calculate the cost of pumping using diesel motor, the price of selling of the diesel oil of $\mathrm{R} \$ 2.40$ $\mathrm{L}^{-1}$ and a consumption of $170 \mathrm{~g} \mathrm{cV}^{-1} \mathrm{~h}^{-1}$ (Marques \& Coelho, 2003) were used. The monthly wage used was R\$ 550.00 month $^{-1}$, plus legal fees.

To analyze the viability of irrigation, the cost to produce a dry-farming system of R\$ 2,600.00 ha-1 (MAPA, 2006) was considered, equivalent to a unit cost of production of produced $\mathrm{R} \$$ $0.83 \mathrm{~kg}^{-1}$, calculated according to Bach $\&$ Lopes (2007); the purchase price of drip irrigation system is $\mathrm{R} \$ 8,000.00$ $\mathrm{ha}^{-1}$, with a rated horsepower of $2 \mathrm{cv}$ $\mathrm{ha}^{-1}$, flow of $2.5 \mathrm{~m}^{3} \mathrm{~h}^{-1}$ and application efficiency $90 \%$.

The calculations used followed the computational model to analyze the economic risk in irrigated crops (Marques \& Frizzone, 2005), in which simulations of economic factors are performed in Triangular Probability Distribution by Monte Carlo method with values obtained in Marques et al. (2006) and Associação Brasileira de Olericultura (2007). The values used for minimum (MIN), modal (MOD) and maximum (MAX) of economic factors were respectively for the oregano selling price of $6.50 ; 8.40$ and $\mathrm{R} \$ 8.60 \mathrm{~kg}^{-1}$; for the irrigation system life span of $10 ; 13$ and 15 years; for the maintenance fee of $2.0 ; 3.0$ and $4.0 \%$; for the interest rate of $8 ; 12$ and $16 \%$ per year; for labor a use of $1.0 ; 2.5$ and 4.0 hours ha ${ }^{-1}$ irrigation $^{-1}$; the water cost $0.00 ; 0.01$ and $\mathrm{R} \$ 0.03 \mathrm{~m}^{-3}$.

The total cost of irrigation (equation 1) was divided into fixed and variable costs. To obtain the annual fixed irrigation costs, the Capital Recovery Factor (Ortiz Romero et al., 2006) was used. The Capital Recovery Factor means sufficient quantity of money in each year to enable the replacement in a number of years plus the charges of interests on the capital investment (Frizzone \& Silveira, 2000; Frizzone et al., 2001; Bach \& Lopes, 2007). In the calculation of annual variable irrigation costs, the pumping cost, maintenance, labor and water costs (Frizzone et al., 2001; Marques \& Coelho, 2003) were used. The annual pumping cost of electric motor was calculated through the total annual billing demand and the total annual billing of consumption (Ortiz Romero et al., 2006). The annual net return of irrigated crop (equation 2) was obtained for the yields of each irrigation levels. The crop net return with no irrigation was calculated using equation 3 . The annual liquid profit of the irrigation (equation 4) is referred to the economic profit obtained through the use of irrigation, which is considered in the calculus of $\mathrm{B} / \mathrm{C}$ relationship that evaluates how much the project pays per unit of investment (equation 5), according to Almeida et al. (2004); Marques \& Frizzone (2005) and Oweis \& Hachum (2009).

$$
\begin{aligned}
& \mathrm{CI}=\mathrm{CF}+\mathrm{Cb}+\mathrm{Cm}+\mathrm{Cmo}+\mathrm{Cw} \\
& \mathrm{RLi}=[\mathrm{Yi} \cdot \mathrm{Pp}-(\mathrm{CP} \cdot \mathrm{Yi})+\mathrm{CI}] \\
& \mathrm{RLs}=[\mathrm{Ys} \cdot \mathrm{Pp}-(\mathrm{CP} \cdot \mathrm{Ys})] \\
& \mathrm{BL}=\mathrm{RLi}-\mathrm{RLs} \\
& \mathrm{B} / \mathrm{C}=\frac{B L}{C I}
\end{aligned}
$$

where: $\mathrm{CI}$ is the annual irrigation cost ( $\mathrm{R} \$$ ha $^{-1}$ year $\left.^{-1}\right)$; $\mathrm{CF}$ is the annual fixed cost $\left(\mathrm{R} \$ \mathrm{ha}^{-1}\right.$ year-1 $)$; $\mathrm{Cb}$ is the annual pumping cost $\left(\mathrm{R} \$ \mathrm{ha}^{-1}\right.$ year $\left.^{-1}\right)$; $\mathrm{Cm}$ is the annual maintenance cost $(\mathrm{R} \$$ $\mathrm{ha}^{-1}$ year $\left.^{-1}\right)$; Cmo is the annual labor cost $\left(\mathrm{R} \$\right.$ ha $^{-1}$ year $\left.^{-1}\right)$; $\mathrm{CW}$ is the annual 
water cost $\left(\mathrm{R} \$ \mathrm{ha}^{-1}\right.$ year $\left.^{-1}\right)$; RLi is the annual net return of the irrigated crop $\left(\mathrm{R} \$\right.$ ha $^{-1}$ year-1 $^{-1}$; RLs is the annual net return of the non-irrigated crop $\left(\mathrm{R} \$ \mathrm{ha}^{-1}\right.$ year $\left.^{-1}\right)$; Yi is the yield of the irrigated oregano for several tested irrigation levels $\left(\mathrm{kg} \mathrm{ha}^{-1}\right.$ year $\left.^{-1}\right)$; $\mathrm{Pp}$ is the price paid for the producer $\left(\mathrm{R} \$ \mathrm{~kg}^{-1}\right)$; $\mathrm{CP}$ is the oregano yield cost without considering the irrigation costs $\left(\mathrm{R} \$ \mathrm{~kg}^{-1}\right)$; Ys is the oregano dry-farming crop yield $\left(\mathrm{kg} \mathrm{ha}^{-1}\right.$ year $\left.^{-1}\right)$; BL is the annual liquid profit ( $\mathrm{R} \$$ $\mathrm{ha}^{-1}$ year $^{-1}$ ) and $\mathrm{B} / \mathrm{C}$ is the cost-benefit rate.

According to Zocoler (2003), for the electric motor, it is important to consider the tariff system of electric energy. This way, four pumping systems are considered (electric motor with green, blue and conventional tariff and diesel motor). Three different tariffs (conventional, blue and green) can be used and two basic components define the price: One is related to the power demand, and the other one is related to the energy consumption. The annual pumping cost for the electric motor is calculated by the total billing demand and total billing consumption related to the type of season tariff. In the calculation of blue and green season tariff prices, some differences are based on the use of the electric energy during the day hours and during the season of the year (Marques \& Frizzone, 2005). The day hours are divided into peak hour (in state of São Paulo, three consecutive hours, from 6 to 9 p.m.) and the nonpeak hour corresponding to the rest of the hours of the day but the peak ones defined by ANEEL, 2009. Each modality of pumping resulted in 31,250 combined values of annual liquid profit $\left(\mathrm{R} \$ \mathrm{ha}^{-1}\right.$ year $^{-1}$ ) which were separated into 10 classes of frequency for adherence analysis by Kolmogorov-Smirnov to the normal probability density function with level of $5 \%$ of significance. After the confirmation of the adherence, the calculus of the probability of irrigation feasibility was done. That means, liquid profit higher than zero.

\section{RESULTS AND DISCUSSION}

For all tested pumping modalities with all the irrigation levels, the probability of liquid profit obtained was $100 \%$ higher than zero, that means, annual net returns higher than the net returns of the non-irrigated oregano and consequently all of them showed cost-benefit relationship higher than 1. (Tables 1 and 2). For non-irrigated oregano, the annual net return was $\mathrm{R} \$$ $21,907.66$ ha $^{-1}$ year ${ }^{-1}$ with a standard deviation of $1,468.9 \pm 6.7 \%$.

These results show that irrigation is viable for oregano, according to Frizzone \& Silveira (2000) a project should present a cost/benefit rate higher than one to be viable and, the higher this relationship, more attractive is the project (Clark et al., 1993). Concerning this information, the most attractive irrigation depth was the one 100\% using electric motor with blue or green tariff with a cost-benefit rate of 4.97 . Better results for yield and net return for oregano were obtained by Hadid et al. (2004) irrigation depth, corresponding to $100 \%$ ECA in Syria. For irrigated coffee using drip irrigation in Lavras (Silva et al., 2003), the replacement of $100 \%$ of Class A pan evaporation also showed the best economic viability. Kirnak \& Dogan (2009) studied different irrigation depth based on Class A pan, in semi-arid conditions, also observed that the higher yield was obtained using $100 \%$ ECA.

For risk values measured by the standard deviation (Table 2), all the irrigation depth provided percentage values lower to production risk of the dry-farming crop $( \pm 6.7 \%)$, which is only linked to changes in market prices. With the use of the irrigation the distribution of the probabilities of the other simulations diluted the wide variation promoted by the selling price of the oregano. In a sensitivity analysis, the result obtained was that the selling price of the oregano when submitted to a percentage variation of $\pm 20 \%$, promoted an average variation of $\pm 26.5 \%$ in annual net return. The other economic factors showed values always lower than $\pm 1.5 \%$. The factor that promoted a lower influence was the water cost with values always lower than $\pm 0.5 \%$.

The annual fixed cost of the irrigation equipment considering all the combinations resulted in an expected value of R\$1,262.60 a year. The average expected values obtained using the four types of pumping for irrigation in the oregano crop, in the region of Presidente Prudente, for the different irrigation depths, are shown in Table 3.

In this work, the irrigation cost represented $35.8 ; 36.1 ; 35.1$ and $28.4 \%$ of the total production cost. These values agreed with Pavlov et al. (2006), which consider that the irrigation costs are high, it can reach $40 \%$ of the total production cost. On the other hand, a

Table 1. Annual net received (RLi) and annual net benefit (BL) expected $\left(\mathrm{R} \$ \mathrm{ha}^{-1} \mathrm{yr}^{-1}\right)$ for the four water depths tested considering four pumping kinds (receita líquida e benefício líquido esperados anuais ( $\mathrm{R} \$ \mathrm{ha}^{-1} \mathrm{ano}^{-1}$ ) para quatro lâminas em quatro modalidades de bombeamento). Presidente Prudente, UNOESTE, 2009.

\begin{tabular}{lccc}
\hline Pumping kind & Water depth (\%ECA) & RLi & BL \\
\hline \multirow{2}{*}{ Diesel oil } & $25 \%$ & $32,472.60$ & $10,564.94$ \\
& $50 \%$ & $34,193.31$ & $12,285.65$ \\
& $75 \%$ & $37,009.21$ & $15,101.55$ \\
\multirow{2}{*}{ electric motor tariffs blue and } & $100 \%$ & $53,494.18$ & $31,586.52$ \\
green & $25 \%$ & $32,589.00$ & $10,681.34$ \\
& $50 \%$ & $34,489.54$ & $12,581.88$ \\
& $75 \%$ & $37,481.64$ & $15,573.98$ \\
electric motor tariffs conventional & $100 \%$ & $54,139.98$ & $32,232.32$ \\
\hline & $25 \%$ & $10,553.17$ & $32,460.83$ \\
& $50 \%$ & $34,352.38$ & $12,444.72$ \\
& $75 \%$ & $37,335.43$ & $15,427.77$ \\
\hline
\end{tabular}

$1 \mathrm{US} \$=\mathrm{R} \$ 2.35$ 
Table 2. Average expected values $(\mathrm{E}(\mathrm{X}))$ obtained for the four water depths considering four pumping kinds (valores médios esperados $(\mathrm{E}(\mathrm{X})$ ) obtidos para quatro lâminas de irrigação considerando quatro modalidades de bombeamento). Presidente Prudente, UNOESTE, 2009.

\begin{tabular}{lcccc}
\hline & \multicolumn{4}{c}{ Water depth (\%ECA) } \\
\cline { 2 - 5 } & $\mathbf{2 5 \%}$ & $\mathbf{5 0 \%}$ & $\mathbf{7 5 \%}$ \\
\cline { 2 - 5 } & \multicolumn{4}{c}{ Diesel motor } \\
\hline $\mathrm{CI}$ & 2427.65 & 2654.44 & 2881.92 & 3116.71 \\
$\mathrm{~B} / \mathrm{C}$ & 3.10 & 3.19 & 3.39 & 4.53 \\
$\sigma$ & $897.5 \pm 2.8 \%$ & $1.025 .8 \pm 3.0 \%$ & $1.213 .2 \pm 3.3 \%$ & $2.340 .2 \pm 4.4 \%$ \\
$\mathrm{P}(\%)$ & $100 \%$ & $100 \%$ & $100 \%$ \\
\hline \multicolumn{5}{c}{ Electric motor, tariffs green and blue } \\
\hline $\mathrm{CI}$ & 2311.25 & 2358.18 & 2409.44 \\
$\mathrm{~B} / \mathrm{C}$ & 3.19 & 3.42 & 3.74 \\
$\sigma$ & $897.5 \pm 2.8 \%$ & $1.025 .8 \pm 3.0 \%$ & $1.213 .2 \pm 3.3 \%$ & $2.340 .2 \pm 4.4 \%$ \\
$\mathrm{P}(\%)$ & $100 \%$ & $100 \%$ & $100 \%$ \\
\hline \multicolumn{5}{c}{ Electric motor, tariffs conventional } \\
\hline $\mathrm{CI}$ & 2439.43 & 2495.35 & 2555.66 \\
$\mathrm{~B} / \mathrm{C}$ & 3.09 & 3.31 & 3.62 & $260 \%$ \\
$\sigma$ & $897.5 \pm 2.8 \%$ & $1.025 .8 \pm 3.0 \%$ & $1.213 .2 \pm 3.3 \%$ & $2.340 .2 \pm 4.4 \%$ \\
$\mathrm{P}(\%)$ & $100 \%$ & $100 \%$ & $100 \%$ \\
\hline
\end{tabular}

$\mathrm{E}(\mathrm{X})=$ average expected values (valores esperados médios); $\mathrm{CI}=$ annual irrigation cost in $\mathrm{R} \$$ ha $^{-1}$ year ${ }^{-1}$ (custo anual da irrigação em $\mathrm{R} \$ \mathrm{ha}^{-1} \mathrm{ano}^{-1}$ ); $\mathrm{B} / \mathrm{C}=$ benefit/cost relation (relação benefício custo); $\sigma=$ standard deviation used as a risk measuring in $\%$ (desvio padrão usado como medida do risco em $\%$ ); $\mathrm{P}(\%)=$ probability of annual net benefit $>0$ (probabilidade de benefício líquido anual $>0$ ).

detailed study on the irrigation costs is necessary, in order to identify the most important factors in the formation of the annual irrigation cost.

Studying the annual cost of irrigation, the participation of involved economic factors (Table 3) was evaluated separately. The fixed and variable costs remained around $50 \%$ share of the annual cost of irrigation, for all kinds of pumping and all irrigation levels. The high share of the fixed cost is due to the high value of the acquisition of the drip irrigation system, which requires fixed system in the field, good filtering and multiple records. Blanco et al. (2004) also observed that the cost of the equipment acquisition associated to the life span are the higher sensitivity factors in the fixed irrigation costs.

Evaluating the kinds of pumping, the diesel motor provided lower net returns followed by the conventional electric tariff. The study in order to choose the kind of pumping and the electric tariff is an important step in this project. Andrade Júnior et al. (2001) considered that among the the increase of the water and pumping costs. Similar results were obtained by Silva et al. (2007) for sunflower harvesting period.

Among the variable costs, the labor participation highlights (24 to $29 \%$ of the irrigation cost). The high frequency of irrigation, during 75 days in a 90-day cycle, leaded to a constant use of labor during the period, resulting in higher costs. Another factor to be considered is that trickle irrigation requires a more technified labor, which receives a better wage than the field laborers.

Concerning the pumping cost, a high share was expected, just like the one obtained by Andrade Júnior et al. (2001) for watermelon grown by drip irrigation in semi-arid region where the use of deficit irrigation showed higher net returns. Marques \& Frizzone (2005), for sugar cane irrigated by central pivot and self-propelled obtained values higher than $50 \%$. However, in this experiment, maximum values of $28.37 \%$ were observed for the use of diesel motor only due to the high cost of the liter of diesel and the impossibility of special values use during the non-peak hours just like for the electric motor. For the electric motor the values were always lower than $15 \%$. These results were obtained due to the use of low pressure and high frequencies, common characteristics of the trickle irrigation systems that require a low power pump and little time of irrigation.

The maintenance rate showed average values from 7 to $10 \%$ of the annual irrigation cost. The charge for the use of the water was the factor that most influenced in the annual net return with values always lower than $1.2 \%$ of the total irrigation cost, the same results obtained by Blanco et al. (2004) and Marques \& Frizzone (2005).

Thus, this study concluded that the average values of cost-benefit rate for all tested irrigation depths were higher than 1 , indicating economic viability. The use of irrigation promoted economic risks lower than the use of dry-farming system. For the risks, the indicators obtained confirm that the use of trickle irrigation showed higher sensitivity to the variation of the acquisition costs associated to the variation of 
Table 3. Percentage share of irrigation costs in the total cost of irrigation obtained for the four irrigation depths considering the four pumping kinds (participação percentual dos custos advindos da irrigação no custo total da irrigação obtidos para quatro lâminas de irrigação considerando as quatro modalidades de bombeamento). Presidente Prudente, UNOESTE, 2009.

\begin{tabular}{|c|c|c|c|c|}
\hline \multirow{3}{*}{$\begin{array}{l}\text { Total anual } \\
\text { irrigation cost }\end{array}$} & \multicolumn{4}{|c|}{$\%$ do CT } \\
\hline & \multicolumn{4}{|c|}{ Water depth (\%ECA) } \\
\hline & $25 \%$ & $50 \%$ & $75 \%$ & $100 \%$ \\
\hline & \multicolumn{4}{|c|}{ Pumping Diesel oil } \\
\hline $\mathrm{CF}$ & 52.00 & 47.50 & 43.75 & 40.50 \\
\hline $\mathrm{CV}$ & 48.00 & 52.50 & 56.25 & 59.50 \\
\hline Cmo & 28.74 & 26.25 & 24.16 & 22.56 \\
\hline $\mathrm{Cm}$ & 9.85 & 9.08 & 8.36 & 7.64 \\
\hline $\mathrm{Cb}$ & 9.11 & 16.64 & 22.98 & 28.37 \\
\hline \multirow[t]{2}{*}{$\mathrm{Cw}$} & 0.30 & 0.53 & 0.75 & 0.93 \\
\hline & \multicolumn{4}{|c|}{ Electric motor, tariffs blue and green } \\
\hline $\mathrm{CF}$ & 54.62 & 53.46 & 52.32 & 51.09 \\
\hline $\mathrm{CV}$ & 45.38 & 46.54 & 47.68 & 48.91 \\
\hline Cmo & 30.35 & 29.55 & 28.90 & 28.45 \\
\hline $\mathrm{Cm}$ & 10.35 & 10.22 & 10.00 & 9.77 \\
\hline $\mathrm{Cb}$ & 4.37 & 6.18 & 7.90 & 9.53 \\
\hline \multirow[t]{2}{*}{$\mathrm{Cw}$} & 0.31 & 0.59 & 0.88 & 1.16 \\
\hline & \multicolumn{4}{|c|}{ Electric motor, tariffs conventional } \\
\hline $\mathrm{CF}$ & 51.75 & 50.52 & 49.33 & 48.07 \\
\hline $\mathrm{CV}$ & 48.25 & 49.48 & 50.67 & 51.93 \\
\hline Cmo & 28.75 & 27.93 & 27.27 & 26.76 \\
\hline $\mathrm{Cm}$ & 9.81 & 9.66 & 9.43 & 9.19 \\
\hline $\mathrm{Cb}$ & 9.39 & 11.33 & 13.16 & 14.88 \\
\hline $\mathrm{Cw}$ & 0.30 & 0.56 & 0.81 & 1.10 \\
\hline
\end{tabular}

$\overline{\mathrm{CT}}=$ total irrigation cost (custo total da irrigação); $\mathrm{CF}=$ fixed irrigation cost (custo fixo da irrigação); $\mathrm{CV}=$ variable irrigation cost (custo variável da irrigação); $\mathrm{Cb}=$ pumping cost (custo do bombeamento); $\mathrm{Cm}=$ maintenance cost (custo da manutenção); $\mathrm{Cmo}=$ labor cost (custo da mão de obra); $\mathrm{CW}=$ water cost (custo da água).

the life span of the system. Due to the characteristics of the high frequency of the trickle irrigation, no differences were observed between green and blue season tariffs. So the use of the irrigation for the oregano in Presidente Prudente region is indicated due to the economic viability and the decrease of risks, considering the appropriate management for drip irrigation to the application of $100 \%$ ECA with electric motor using the green or blue tariff.

\section{REFERENCES}

ALMEIDA FT; BERNARDO S; SOUSA EF; MARIN SLD; GRIPPA S. 2004. Análise econômica baseada em funções de resposta da produtividade versus lâminas de água para o mamoeiro no Norte Fluminense. Engenharia
Agrícola 24: 675-683.

ANDRADE JÚNIOR AS; FRIZZONE JA; BASTOS EA; CARDOSO MJ; RODRIGUES BHN. 2001. Estratégias ótimas de irrigação para a cultura da melancia. Pesquisa Agropecuária Brasileira 36: 301-305.

ANEEL (2009) Agência nacional de energia elétrica. 2009, 20 de agosto. Resolução homologatória $n^{\circ} 735$, de 4 de novembro de 2008. Disponível em: http://www.aneel.gov. br/cedoc/reh2008735.pdf

ASSOCIAÇÃO BRASILEIRA DE OLERICULTURA 2007, 02 de fevereiro de 2008. Cotações de produtos agrícolas do dia 31 de janeiro de 2008. Disponível em http://www.abhorticultura.com.br/Cotacoes/ Default.asp?!b=1

BACH DB; LOPES MA. 2007. Estudo da viabilidade econômica do cultivo da babosa (Aloe vera L.). Ciência e Agrotecnologia 31: 1136-1144.

BLANCO FF; MACHADO CC; COELHO RD; FOLEGATTI, MV. 2004. Viabilidade econômica da irrigação da manga para o estado de São Paulo. Revista Brasileira de Engenharia Agrícola e Ambiental 8: 153159, 2004.

CLARK E; JACOBSON K; OLSON DC. 1993. Avaliação econômica e financeira de projetos de irrigação. Brasília: Ministério da Integração Nacional/Secretaria da Irrigação, 170p. (Manual de irrigação, 3).

EMBRAPA 1999. Sistema brasileiro de classificação de solos. Brasília: Embrapa-SPI, Embrapa-CNPS, 412p.

FRIZZONE JA; SILVEIRA SFR. 2000. Análise econômica de projetos hidroagrícolas. In: SILVA DD; PRUSKI FF (eds). Gestão de recursos hídricos: aspectos legais, econômicos, administrativos e sociais Brasília: Secretaria de Recursos hídricos, p. 449-617.

FRIZZONE JA; BOTREL TA; FREITAS HAC. 1994. Análise comparativa dos custos de irrigação por pivô-central, em culturas de feijão, utilizando energia elétrica e óleo diesel. Engenharia Rural 5: 34-53.

FRIZZONE JA; MATIOLI CS; REZENDE R; GONÇALVES ACA. 2001. Viabilidade econômica da irrigação suplementar da canade-açúcar, Saccharum spp., para a região Norte do Estado de São Paulo. Acta Scientiarum 23: 1131-1137.

HADID AA; BATANOUNY KH; JABARINE AS; KADER AA. 2004. Proposal for expanding the crop mandate of ICARDA to include horticultural crops. Syria: International Center for Agricultural Research in the Dry Areas (ICARDA), 54p.

IGLESIAS E; GARRIDO A; GÓMEZ-RAMOS A. 2003. Evaluation of drought management in irrigated areas. Agricultural Economics 29: 211-229.

KIRNAK H; DOGAN E. 2009. Effect of seasonal water stress imposed on drip irrigated second crop watermelon grown in semi-arid climatic conditions. Irrigation Science 27: 155-164.

MAPA 2006. Boas práticas agrícolas (BPA) de plantas medicinais, aromáticas e condimentares. Brasília: MAPA/SDC, 48p.

MARQUES PAA; COELHO RD. 2003. Estudo da viabilidade econômica da pupunha (Bactris Gasipaes H.B.K) para Ilha Solteira-SP, Brasil. Ciência Rural 33: 291-297.

MARQUES PAA; FRIZZONE JA. 2005. Modelo computacional para determinação do risco econômico em culturas irrigadas. Acta Scientiarum 27: 725-733.

MARQUES PAA; MARQUES TA; FRIZZONE JA. 2006. Viabilidade econômica sob condições de risco para a irrigação da canade-açúcar na região de Piracicaba-SP. Revista Irriga 11: 55-65.

MARQUES PAA; BERNARDI FILHO L; OLIVEIRA RB. 2009. Oregano production under various water depths estimated by means of the class A pan evaporation. Horticultura Brasileira 27: 59-63.

MASTRO G; RUTA G; MARZI V. 2004. Agronomic and technological assessment of oregano (Origanum vulgare ssp.) biotypes. Acta Horticulturae 629: 355-363.

MOUSINHO FEP; ANDRADE JÚNIOR AS; FRIZZONE JA. 2008. Viabilidade econômica 
do cultivo irrigado do feijão-caupi no Estado do Piauí. Acta Scientiarum 30: 139-145.

ORTIZ ROMERO JN; MARTÍNEZ JM; MARTÍNEZ RS; MARTÍN-BENITO JMT. 2006. Set sprinkler irrigation and its cost. Journal of Irrigation and Drainage Engineering. 132: 445-452.

OWEIS T; HACHUM A. 2009. Optimizing supplemental irrigation: tradeoffs between profitability and sustainability. Agricultural Water Management 96: 511-516.

PAVLOV SS; ROERINK PJG; HELLEGERS J; POPOVYCHI VF. 2006. Irrigation performance assessment in Crimea, Ukraine. International Journal of Water Resources Development 22: 61-78.

SILVA AL; FARIA MA; REIS RP. 2003. Viabilidade técnico-econômica do uso do sistema de irrigação por gotejamento na cultura do cafeeiro. Revista Brasileira de Engenharia Agricola e Ambiental 7: 37-44.

SILVA MLO; FARIA MA; REIS RP; SANTANA MJ; MATTIOLI W 2007. Viabilidade técnica e econômica do cultivo de safrinha do girassol irrigado na região de Lavras, MG. Ciência e Agrotecnologia 31: 200-205.
SOUZA JLM; FRIZZONE JA 2003. Modelo aplicado ao planejamento da cafeicultura irrigada. I. simulação do balanço hídrico e do custo com água. Acta Scientiarum 25: 103-112.

VAN GENUCHTEN MTH. 1980. A closedform equation for predicting the hydraulic conductivity of unsaturated soils. Soil Science Society of America 44: 892-898.

ZOCOLER JL. 2003. Análise econômica de sistemas de irrigação. In: MIRANDA JH; PIRES RCM (eds) Irrigação Jaboticabal: Funep, p.653-703. (Série Engenharia Agrícola, 2). 